Jan Wnęk

PWSZ w Krośnie

Zakład Pedagogiki

Instytut Humanistyczny

\title{
Działalność naukowa Jana Kuchty
}

\begin{abstract}
Abstrakt. Jan Wnęk, The Scholarly Activity of Jan Kuchta
The article presents the scholarly activity of Jan Kuchta in the interwar period and discusses the contents of his articles and books. The author discusses in detail the essential contents of the following books: Książka zakazana jako przedmiot zainteresowań młodzieży w okresie dojrzewania („A Forbidden Book As an Object of Interest of Adolescent Youth”); Dziecko włóczęga (“A Child Vagabond"); Nowe kierunki i dążenia współczesnej katolickiej pedagogiki [na tle obrazu chaosu we współczesnym wychowaniu] ("New Trends and Endeavours of Catholic Pedagogics [on the Background of the Image of Chaos in Modern Upbringing])". These books, as well as other Kuchta's works, popularized a number of problems from various fields of knowledge, such as ethnography, pedagogy, psychology and sociology. However, these were not creative treaties constituting a significant contribution to the Polish science.
\end{abstract}

Keywords: Jan Kuchta

W publikacjach dotyczących dziejów nauki i oświaty polskiej wiele miejsca poświęca się postaciom wybitnym, związanym z poszczególnymi dyscyplinami wiedzy. Mniejszą natomiast uwage przywiązuje się do twórczości osób, które w czasach swej działalności nie odegrały istotniejszej roli, nie wpłynęły znacząco na formowanie się nowych prądów i kierunków w nauce. Jest to poniekąd zrozumiałe. Wydaje się jednak, że współcześnie warto przybliżać sylwetki i osiągnięcia niektórych mniej znanych uczonych, tworzących 
w czasach minionych. Pozwoli to bez wątpienia lepiej poznać rozwój wiedzy i kultury w poszczególnych epokach historycznych.

Rozwój nauki polskiej i myśli pedagogicznej determinowały wydarzenia polityczne. Doniosłe znaczenie miało odzyskanie przez Polskę niepodległości w 1918 r. Spowodowało ono, że oświata i nauka, uwolnione od kurateli państw zaborczych, mogły rozwijać się wówczas w sposób nieskrępowany ${ }^{1}$. Jedną z postaci działających aktywnie naukowo w czasach II Rzeczypospolitej był Jan Kuchta - przedstawiciel religijnej myśli wychowawczej², badacz posiadający dorobek z takich dziedzin wiedzy, jak pedagogika, psychologia, etnografia, socjologia dziecka. Urodził się we Lwowie, gdzie zdobył wykształcenie średnie i wyższe. Podczas studiów na Wydziale Teologicznym Uniwersytetu Jana Kazimierza wyjechał do Wiednia, studiując tam filozofię i religioznawstwo. Po powrocie do Lwowa ukończył studia na Wydziale Filozoficznym UJK. Pracował w gimnazjum ruskim w Przemyślu jako nauczyciel języka polskiego oraz historii. Następnie był wykładowcą Państwowych Kursów Nauczycielskich, pracownikiem Ministerstwa Wyznań Religijnych i Oświecenia Publicznego (instruktor szkolnictwa średniego), dyrektorem Centralnej Biblioteki Pedagogicznej w Lwowie, redaktorem serii wydawniczej Lwowska Biblioteka Pedagogiczna oraz serii Biblioteka Licealna Filozoficzna ${ }^{3}$.

\section{Etnografia}

Niewielką liczbę publikacji poświęcił Kuchta problematyce etnograficznej. Zajmował się nią w okresie swej młodości. Pomocne były dla niego wskazówki merytoryczne uzyskiwane od Jana Stanisława Bystronia - wytrawnego znawcy zagadnień etnograficznych. Owocem prac badawczych Kuchty była rozprawa pt. Krakowski czarnoksiężnik XVI wieku. Mistrz Twardowski. Otrzymał za nią na Uniwersytecie Jagiellońskim tytuł doktora ${ }^{4}$. Jej fragmenty ukazały się na łamach czasopisma „Lud” z 1929 r. ${ }^{5}$ Studium to przyczyniło się w jakimś stopniu do spopularyzowania problematyki etnograficznej okresu renesansu.

Wcześniej, bo w 1926 r. ogłosił Kuchta w „Ludzie” artykuł pt. Polskie podania ludowe o człowieku na księżycu ${ }^{6}$. Przedstawił w nim genezę podań, omówił rodzaje obcych podań ludowych o plamach na księżycu, scharakteryzował polskie podania ludowe

\footnotetext{
${ }^{1}$ B. Jaczewski, Organizacja i finansowanie nauki polskiej w okresie międzywojennym, Wrocław - Warszawa - Kraków - Gdańsk 1971; J.A. Kłosiński, Nauka polska w wieku XIX i XX. Studium naukometryczne, Wrocław 1981; B. Jaczewski, Organizacje i instytucje życia naukowego w Polsce (listopad 1918-1939), w: Historia nauki polskiej, t. V: 1918-1951, red. B. Suchodolski, Wrocław - Warszawa - Kraków - Gdańsk 1992.

2 L. Chmaj, Prądy i kierunki w pedagogice XX wieku, Warszawa 1963, s. 457.

3 Kuchta Jan Andrzej, w: Czy wiesz kto to jest?, Warszawa 1983, s. 163; W. Wincławski, Kuchta Jan Andrzej (1900 - ?), w: Słownik biograficzny socjologii polskiej, t. 2, Torun 2004, s. 177.

${ }^{4}$ Ibidem

5 J. Kuchta, Rodzinne watki lokalne w podaniach o mistrzu Twardowskim, „Lud” t. 28, 1929, s. $123-144$.

${ }^{6}$ J. Kuchta, Polskie podania ludowe o człowieku na księżycu, „Lud” t. 25, 1926, s. 38-51.
} 
o człowieku na księżycu. Autor artykułu dawał wyraz przekonaniu, że wierzenia ludowe związane z księżycem stanowią pozostałość po kulcie rozpowszechnionym wśród ludów koczowniczych: Księżyc odwieczny towarzysz ziemi, który w różnych postaciach przechadza się po sklepieniu niebieskim i sprowadza zadziwiajace zmiany atmosferyczne, mógł łatwo zaciekawić różne ludy $i$ wzbudzić $w$ nich wiarę, że w czasie swej wędrówki po niebie bada dokładnie życie człowieka, zna jego cierpienia i przejmuje się nimi ${ }^{7}$. Kuchta zwrócił uwagę, że księżyc był w przekonaniu wielu ludów miejscem kary dla występnych. Autor czerpał wiedzę zarówno z literatury obcojęzycznej, jak i polskiej, w tym m.in. z dzieł Oskara Kolberga, Seweryna Udzieli.

Twórczość Kuchty z zakresu etnografii ustępowała pod względem ilościowym jego dorobkowi z takich dziedzin, jak pedagogika, psychologia. Rozprawa o czarnoksiężniku Twardowskim posiadała niewątpliwie znaczną wartość naukową, skoro młody autor otrzymał za nią tytuł doktora. W badaniach etnograficznych mógł Kuchtę fachowo ukierunkować Bystroń, z którym konsultował się.

\section{Prace psychologiczno-pedagogiczne}

Podział dorobku naukowego J. Kuchty na publikacje psychologiczne, pedagogiczne i socjologiczne sprawia pewne trudności. Niektóre jego artykuły i publikacje książkowe uzupełniały się nawzajem, treść ich traktowała na przemian o psychologii i pedagogice. Wiele prac naukowych z okresu międzywojnia było pisanych w taki sposób. Miało to związek z dynamicznym rozwojem nowych kierunków i dążeń w psychologii oraz pedagogice. Specjaliści coraz częściej posługiwali się określeniem psychologii pedagogicznej, tj. psychologii zastosowanej do potrzeb pedagogiki. Znany psycholog, Stefan Szuman, napisał w 1929 r.: W psychologii ostatnich dziesiątek lat namnożyło się [...] teorii i poglądów bardzo wiele, co [...] świadczy o niedojrzałości tej nauki, ale również o jej żywotności. Z punktu widzenia nauk pedagogicznych ten rozwój psychologii stanowi, [...] znaczny postęp. Psychologia jest jedna z nauk podstawowych dla teoretycznych rozważań i praktycznych poczynań pedagogiki. Jestem zdania, że dzięki rozwojowi w ostatnich kilku dziesięcioleciach nauka ta stała się wiele doskonalszym narzędziem pedagogiki niż była dawniej $i$ że dopiero teraz pedagogika zaczyna osiagać prawdziwe dla siebie korzyści z psychologii ${ }^{8}$.

Jan Kuchta był świadomy faktu różnych kierunków w pedagogice i psychologii. Na początku lat 30. ubiegłego stulecia stwierdzał: Poglądy torujace sobie droge w psychologii harmonizuja z tendencjami pedagogicznymi obecnej doby, mają więc żywotne znaczenie dla pedagogiki i nie moga być pomijane9. Młody uczony interesował się wówczas psychologicznymi typami ludzi ${ }^{10}$. Dał temu wyraz w publikacji Typy uczniów, ogłoszonej

\footnotetext{
7 J. Kuchta, Polskie podania ludowe o człowieku na księżycu, Lwów 1927, s. 3.

8 S. Szuman, Nowe kierunki psychologii a pedagogika, „Chowanna” t. 1, 1929, s. 3.

9 J. Kuchta, Typy uczniów, „Miesięcznik Pedagogiczny” 1931, s. 268.

10 J. Kuchta, Psychologiczne typy C. G. Junga, „Ruch Pedagogiczny” 1930, s. 217 i n.
} 
na łamach „Miesięcznika Pedagogicznego”. Powołując się na artykuł A. Kiesslinga, pt. Entwicklungstendenzen der pädagogischen Psychologie (,Zeitschrift für pädag. Psychologie" 1929 r.), analizował nowe kierunki w ówczesnej psychologii niemieckiej oraz anglosaskiej, uznając, że nauczyciel powinien je znać i rozumieć. Pisząc o typach uczniów trudnych do wychowania, podawał, że z ciekawego punktu widzenia charakteryzuje je uczeń Sigmunda Freuda - August Aichhorn w dziele pt. Die verwahrloste Jugend (Zürich 1925): Ujęcie Aichhorna, wprawdzie tylko intuicyjne i jednostronne, bo pod wptywem Freuda wytacznie pozostajace, jest jednak nader cenne, jako , hipoteza robocza" przy pracy wychowawczej, i dlatego zasługuje na baczna uwagę wychowawców w szkole średniej. Jest to zreszta rzecz nowa i bardzo oryginalna a mało niestety znana ${ }^{11}$. Kuchta, kontynuując swoje rozważania przekazywał, że również twórca psychologii indywidualnej - Alfred Adler, zajmuje się typami dzieci (w książkach Die schwer erziehbaren Kinder, oraz Individualpsychologie in der Schule, Berlin 1929) sprawiającymi problemy wychowawcze. Polski autor nawiązywał także do studium wybitnego psychoanalityka szwajcarskiego Carla Gustawa Junga, pt. Psychologische Typen oraz książki Elise Croner zatytułowanej Die Psyche der weiblichen Jugend.

W centrum zainteresowań Kuchty były zagadnienia związane z typologią nauczycie$\mathrm{li}^{12}$. Nie był on jedynym polskim badaczem, który ówcześnie zajmował się tą problematyką $^{13}$. Na pierwszych kartach swego studium Typologia nauczyciela. Szkice wychowawcze, wykazywał, że typologia nauczyciela to jeden z nowych kierunków psychologii, analizujący osobowość nauczyciela-wychowawcy. Autor, powołując się na ustalenia różnych autorów, dokonał charakterystyki poszczególnych typów nauczycieli. Wymieniał: typ religijny (nauczyciel tego typu to człowiek moralny, dzieci poważają go i szanują), teoretyczny (wśród „wartości” wiedzę stawia na pierwszym miejscu, pragnie jej przekazać uczniom jak najwięcej), praktyczny (ekonomiczny; taki nauczyciel chce przygotować swych podopiecznych do dorosłego życia), społeczny (nauczyciel poświęca się dla innych, oddaje ,siebie samego dla ich dobra”), estetyczny (nauczyciela cechuje zdolność „wczuwania się w drugiego człowieka, w tym wypadku wychowanka, zdolność współprzeżywania niejako z nim tego, co on przeżywa"), władczy (polityczny; nauczyciel dąży do tego „by za każdą cenę przeprzeć własną wolę, by wszystko podporządkowywać swym celom życiowym") ${ }^{14}$.

W drugiej części omawianej pracy autor poruszył zagadnienie ściśle związane z osobowością nauczyciela, a mianowicie stosunek nauczyciela do ucznia. Wyjaśniał, że nowoczesna myśl pedagogiczna przywiązuje do postawy wychowawczej wielkie znaczenie. Nie przestrzega się jednak teoretycznych wskazówek w praktyce szkolnej, gdzie postawa wychowawcza jest koszarowa, surowa. Autor był przeciwnikiem zbytniej surowości na-

11 J. Kuchta, Typy uczniów..., s. 271.

12 J. Kuchta, Typologia nauczyciela, „Miesięcznik Pedagogiczny” 1931, s. 302-306.

13 Zob. m.in.: Z. Mysłakowski, Co to jest kontakt pedagogiczny, Kraków 1923; W. Dzierzbicka, O uzdolnieniach zawodowych nauczyciela-wychowawcy, Warszawa 1926; M. Piątkowicz, Osobowość nauczyciela a wychowanie, „Przegląd Pedagogiczny” 1932, nr 36, 38; S. Baley, Psychologia kontaktu wychowawczego, Warszawa 1932.

14 J. Kuchta, Typologia nauczyciela. Szkice wychowawcze, wyd. 2, Lwów 1936, s. 6-15. 
uczycieli wobec dzieci, która - jego zdaniem - jest szkodliwa dla rozwoju charakteru wychowanka: Rzecza kierownika zakładu jest nie dopuścić do tego, by postawa wychowawcza zbyt rażaco odbiegła od tych najogólniejszych norm [...] nie dopuścić do atmosfery szkolnej nieraz nazbyt koszarowej, urzędowej $i$ władczej, a nieraz na odwrót zbyt demagogicznej i dlatego demoralizującej młodzież [...] Szkoła bowiem, nieumiejętnie ustosunkowując się do młodzieży, traci swój autorytet, a nauczyciel wpływ na wychowanka. Zapobiec złemu można przez zapoznanie grona nauczycieli na Radzie pedagogicznej z teoriami postawy wychowawczej oraz zreferowanie podstawowych z tej dziedziny prac naukowych ${ }^{15}$.

Ważną część dorobku naukowego J. Kuchty stanowiły prace oświetlające problematykę rozwoju psychicznego dzieci młodzieży ${ }^{16}$. Jako numer 8 Biblioteki Kwartalnika Pedagogicznego ukazała się jego rozprawa pt. Rozwój psychiczny dziecka wiejskiego. We wstępie do niej autor zwrócił uwagę, że zasadnicze prawa rozwoju psychicznego człowie$k a$, względnie ustalone przez psychologię rozwojowa, obowiazuja $i w$ odniesieniu do dziecka wiejskiego, pozwalając przewidzieć, jaki będzie rozwój każdego normalnego dziecka wsi, kiedy znajdzie się $w$ danej fazie rozwojowej i jaka będzie kolejność poszczególnych faz, przez które przejdzie $e^{17}$. Zdaniem Kuchty, rozwój psychiczny dziecka zależy od trzech czynników, a mianowicie: zadatków wrodzonych, otoczenia (środowiska), historii indywidualnej osobnika. Autor omówił szczegółowo te czynniki, wykazując, że środowisko wiejskie posiada swoiste cechy religijne, duchowo-kulturalne, gospodarcze i rodzinne, przyrodnicze, które wpływają na rozwój dziecka.

Swe rozważania nad dzieckiem wiejskim kontynuował Kuchta w książce Psychologia dziecka wiejskiego a praca szkolna, wydanej w Warszawie w 1934 r. Omawiał w niej różnice między psychiką dziecka wiejskiego a miejskiego. W czasach, kiedy tworzył Kuchta niewiele wiedziano o psychice dziecka wiejskiego. Przyjmowano, że wyobraźnia dzieci wiejskich jest mało aktywna i twórcza, a ich inteligencja ,jakościowo inna”, nie słowna tylko raczej praktyczna. Autor podał wskazówki metodyczne dla nauczycieli pracujących w szkole wiejskiej, wyrażając opinię, że nauczanie powinno być ściśle powiązane ze środowiskiem, w którym żyje dziecko. Kuchta radził, aby lekcje w szkole powszechnej rozpoczynać od zapoznania dzieci z najbliższym otoczeniem, jak dom (jego wygląd, budowa, sposób ogrzewania, zaopatrzenie w wodę), zwierzęta gospodarskie, ogród, warzywa, owoce, rośliny uprawne, chwasty, szkodniki, narzędzia rolnicze, mechaniczna uprawa roli, las, drzewa, jagody, grzyby, zwierzęta dzikie. Następnie zalecał prze-

\footnotetext{
15 Ibidem, s. 31.

16 J. Kuchta, Z badań nad psychiką młodzieży żeńskiej, „Ruch Pedagogiczny” 1930, nr 3, s. 122 i n.; idem, Rozwój psychiczny młodzieży w okresie jej pobytu w szkole powszechnej i średniej, „Miesięcznik Pedagogiczny” 1932, nr 11, s. 289 i n.; nr 12, s. 324 i n.; idem, Pamiętnik współczesnego dziewczęcia, „Muzeum” 1933, z. 3; idem, Psychologiczne podstawy nowych programów, „Miesięcznik Pedagogiczny” 1934, nr 1, s. 18 i n.; nr 2, s. 34 i n.; idem, Jak uczyć języka polskiego w I klasie szkoły powszechnej?, „Miesięcznik Pedagogiczny” 1934, nr 3, s. 85 i n.

17 J. Kuchta, Rozwój psychiczny dziecka wiejskiego, Warszawa 1933, s. 7.
} 
kazywać dzieciom wiedzę na temat przetwarzania płodów rolnych, funkcjonowania tartaków, fabryk, młynów ${ }^{18}$. Uzupełnieniem tej edukacji miała być wycieczka do miasta.

Studium Psychologia dziecka wiejskiego a praca szkolna zawierało wskazówki wychowawcze odnośnie co do kształtowania przez nauczycieli uczuć dziecięcych. Autor uważał, że uczucia młodzieży wiejskiej zabija twardość $i$ surowość życia, powodujaca zbytnia twardość w stosunku człowieka do człowieka i świata, utylitarystyczne traktowanie wszystkiego. Środek do zaszczepienia w dziecku uczuć moralnych dostrzegał Kuchta W nauce religii i modlitwie ${ }^{19}$. Zalecał wykorzystywać przy nauce religii jako materiał dydaktyczny dewocjonalia, śpiewać pieśni nabożne. Pisząc o potrzebie rozwijania uczuć społecznych i obywatelskich, postulował przystąpić do pracy nad systematycznym wychowaniem dziecka wsi w duchu obywatelsko-państwowym, rozbudzeniem jego uczuć dla Państwa i osób na jego czele stojacych, tudzież bohaterów, którzy wywalczyli mu byt niepodlegty ${ }^{20}$. Z kolei kształtowanie uczuć intelektualnych i estetycznych zalecał Kuchta realizować przez gry i zabawy, uwrażliwianie dzieci na piękno ${ }^{21}$.

O rozwoju psychicznym dzieci i młodzieży pisał Kuchta również w takich pracach, jak Psychologiczne podstawy nowych programów; Rozwój psychiczny młodzieży a praca szkolna ${ }^{22}$. Omawiał w nich schematycznie okresy w życiu młodego człowieka, wyróżniając okres średniego dziecięctwa (do lat 7), późnego (do roku 12), okres przedpokwitania (do roku 14), pokwitania (do roku 18) i okres młodzieńczy (do roku 21). Książki Kuchty z tego zakresu uchodziły za studia praktyczne, pomocne dla nauczycieli i wychowawców ${ }^{23}$.

Swe przemyślenia pedagogiczno-psychologiczne wyłożył Kuchta w publikacjach traktujących o czytelnictwie dzieci i młodzieży. Na łamach „Miesięcznika Pedagogicznego" z 1933 r. podzielił się z odbiorcami pisma swymi refleksjami na temat roli czasopisma szkolnego i jego celów, wykazując, że ma ono ważne znaczenie edukacyjne, kieruje zainteresowania uczniów na takie przedmioty, jak język polski, historia ojczysta. Uważał, że gazetka szkolna nie tylko edukuje, ale i także wychowuje uczniów, daje wierny obraz życia szkoły i młodzieży, ponadto może stanowić impuls do gromadzenia zbiorów przyrodniczych, tworzenia muzeów regionalnych, archiwów historycznych, szkolnych. Na końcu swych rozważań napisał autor takie słowa: Zachwycamy się niejednokrotnie nowymi kierunkami zagranicznymi, bardzo stusznie zreszta [...] Ale przyznajmy sami: , ileż to u nas nieraz robi się po cichych, odległych wiejskich szkołach ciekawych prób $i$ nowych rzeczy?" Nie na efekt oczywiście! Bo te ciche talenty, urodzone, nasze, nie lubia reklamy. Robia to cicho, jakby robili coś zupetnie zwyktego. I tylko jakiś nadzwyczajny wypadek (przypadkowa wizytacja jakiegoś wybitnego pedagoga) wydobywa te ,poczynania” na

18 J. Kuchta, Psychologia dziecka wiejskiego a praca szkolna, Warszawa 1934, s. 64.

19 Ibidem, s. 70.

20 Ibidem, s. 71.

21 Ibidem, s. 73.

22 J. Kuchta, Psychologiczne podstawy nowych programów, Warszawa 1932; idem, Rozwój psychiczny młodzieży a praca szkolna, wyd. 3, Warszawa 1934.

${ }_{23}$ S. Stendig, Szkoła a czytelnictwo pedagogiczne. (Rozważania na tle literatury przedmiotu), ,Miesięcznik Pedagogiczny" 1938, nr 5, s. 137-138. 
światto dzienne. A jak cenne sq one nieraz. Pisemko szkolne pozwoliłoby-dając wspótczesnym ich obraz - i innym, może mniej inicjatywy, a dużo dobrej woli majacym jednostkom, na podjęcie podobnych prób, poznania nowych dróg ${ }^{24}$. Kuchta wierzył w pozytywną i kształcącą rolę czytelnictwa, mniemał, że gazetki szkolne mogą stać się ważnymi nośnikami wiedzy naukowej, a także informatorami o pracy dydaktycznej. Wydaje się jednak, że jego postulaty odnośnie do druku czasopism były trudne do zrealizowania w warunkach ekonomicznych II Rzeczypospolitej.

W okresie międzywojennym dosyć często poruszanym zagadnieniem był problem odpowiedniej lektury dla młodzieży ${ }^{25}$. Badał go również J. Kuchta, a wyniki swych prac przedstawił w rozprawie Ksiązka zakazana jako przedmiot zainteresowań młodzieży w okresie dojrzewania ${ }^{26}$. Zadedykował ją Niestrudzonemu pionierowi nowych kierunków psychologicznych $i$ wychowawczych w Polsce Prof. U. J. Dr. Stefanowi Szumanowi [...] $w$ dowód głębokiej czci $i$ wdzięczności ${ }^{27}$. Autor zdefiniował pojęcie książki zakazanej, pod którym rozumiał tego rodzaju książkę, co do której młodociany jej czytelnik, względnie czytelniczka, ma to przekonanie subiektywne, że jej z tych lub innych względów w danym wieku jeszcze czytać nie należy $y^{28}$.

Kuchta był przekonany, że książka zakazana czytana przez młodego człowieka wywiera potężny wpływ na późniejsze jego losy, jego przyszły światopogląd. Autor, prowadząc badania, doszedł do przekonania, że młodzież do sięgnięcia po książkę zakazaną popycha: ,grzeszna ciekawośc”” (żądza zdobycia za wszelka cenę „, niedozwolonych wiadomości z dziedziny życia płciowego”); chęć ,niedozwolonych przeżyć, przeważnie erotycznych”; pragnienie rozwiązania „,dręczacych zasadniczych problemów, pozbycia się pewnych wątpliwości $i$ usunięcia niepewności, dotyczacych dziedzin życia religijnego, społecznego, politycznego, nauki”; bunt „przeciw zakazowi, skłaniajacy do czytania książki, dla której nie odczuwa się zresztą żadnego, specjalnego zainteresowania, a która czyta sie jedynie dlatego, że jest zakazana ${ }^{29}$.

Autor materiał do swej książki gromadził za pomocą ankiet. Przeprowadzał je w Warszawie, Krakowie i Lwowie, zbierając odpowiedzi od 116 osób dorosłych, przeważnie nauczycieli i dyrektorów szkół średnich. Ponadto zebrał około 1800 odpowiedzi od młodzieży szkół średnich. Ta bogata podstawa źródłowa pozwoliła mu sklasyfikować książki zakazane, wyróżnić pewne ich rodzaje, a mianowicie: książki o treści kryminalnej i sensacyjno-awanturniczej; książki z „dziedziny życia płciowego”, „powieści erotyczne i li-

24 J. Kuchta, Pismo szkolne, „Miesięcznik Pedagogiczny” 1933, nr 11, s. 264.

${ }_{25}$ Zob. m.in.: S. Aleksandrowicz, O lekturze zjadaczy książek, Lwów 1922; H. Radlińska, Rola książki i biblioteki w szkole twórczej, Warszawa 1927; eadem, Potrzeba badania czytelnictwa młodzieży szkolnej, Lwów 1928; eadem, Książka wśród ludzi, Warszawa 1929; H. Radlińska, M. Gutry, B. Grosglikowa, Czytelnictwo dzieci i młodzieży, Warszawa 1932; M.J. Ziomek, Czytelnictwo powieści. Najulubieńsi pisarze i najpoczytniejsze książki, Kraków 1931; idem, Czytelnictwo powieści w Polsce w świetle cyfr, Kraków 1933.

${ }^{26}$ Jej fragmenty ukazywały się wcześniej na łamach „Muzeum” - zob. J. Kuchta, Książka zakazana, „Muzeum” 1931, s. 154, 207, 276.

27 J. Kuchta, Książka zakazana jako przedmiot zainteresowań młodzieży w okresie dojrzewania, Warszawa 1934, s. 5.

28 Ibidem, s. 9.

29 Ibidem, s. 10-11. 
teratura pornograficzna"; zakazane książki treści religijnej, a także zakazane książki naukowe (społeczne, etyczne, przyrodnicze). Kuchta ustalił, że znaczną grupę czytelników książek zakazanych stanowi młodzież w okresie dojrzewania, która sięga po utwory o treściach erotycznych, pióra takich autorów, jak np. Hans Heinz Ewers, Lewis Wallace, Pitigrilli (właśc. Dino Segre). W ocenie autora, książki te porywają wprost młodzież $i$ zachwycają w okresie dojrzewania. Jako dowód przytaczał wypowiedź jednej z czytelniczek: Pożadanie ptciowe budziło się nieraz we mnie silnie [...] myśli tego rodzaju budzity zawsze we mnie pewna odraze $i$ wstręt, chęć pieszczot tkwiła jednak dalej, jakkolwiek głęboko ukryta. Od czasu do czasu objawiała się w podnieceniu, które prowadziło nieubłaganie do zakazanej lektury. Potem podniecenie gasto. Ale zdarzaty się nawroty do jednej i tej samej ksiażki nawet, w takich chwilach podniecenia, lub zdobywało się inna książke, w różny sposób $b^{30}$. Autor pracy Książka zakazana apelował do rodziców o zainteresowanie się tym, co czyta młodzież szkolna, ograniczanie dostępu do literatury, która daje namiastkę przeżyć płciowych. W zakończeniu swej rozprawy stwierdził: Wyczerpawszy temat $w$ najogólniejszych zarysach, pragne jeszcze podkreślić, iz $w$ pracy niniejszej chciałem jedynie zainteresować wychowawców problemem ksiązki zakazanej, oświetliwszy go z różnych stron. O jakieś definitywne rozwiąanie nie kusitem się zupetnie, uważajac, że bytoby to wielce przedwczesne i ryzykowne. Jest to przecież pierwsza praca polska o książce zakazanej. Wyniki zaś pierwszych badań nie upoważniaja z zasady do uogólnień - nie pozwalają na rozstrzygnięcia. Umożliwiają w najlepszym razie jakieś hipotezy. Celem ksiażki byto nadto pobudzenie innych do kontynuowania rozpoczetych badańn ${ }^{31}$.

Z uznaniem o studium Kuchty wypowiadali się krytycy. Twierdzili oni, że autor poruszył wiele nowych zagadnień, dotąd znajdujących słabe omówienie w literaturze naukowej $^{32}$. Wyrażano życzenie, aby wskazówki wychowawcze podane przez Kuchtę były wcielane w życie ${ }^{33}$. Należy zaznaczyć, że twórca rozprawy Książa zakazana wyłożył w niej swe przemyślenia w duchu ideałów katolickich. Nie był pierwszym, który w okresie międzywojnia zajął się problematyką czytelnictwa $\mathrm{z}$ punktu widzenia religijnego ${ }^{34}$. Wśród autorów katolickich panowało przekonanie, że literatura powinna wychowywać ${ }^{35}$.

30 Ibidem, s. 59.

31 Ibidem, s. 141-142.

32 Recenzja, „Polonista” 1932, z. 1-2, s. 33-34.

${ }_{33}$ K. Króliński, recenzja, „Nowa Książka” 1935, z. 2, s. 90.

${ }^{34}$ Zob. m.in.: W. Miemiec, Powieść w świetle etyki, „Ateneum Kapłańskie” t. 26, 1930, s. 268-281; M. Pirożyński, Co czytać? Poradnik w sprawie lektury religijnie uświadamiajacej dla maturzystów szkót średnich ogólnokształcacych i seminariów nauczycielskich, cz. 1: Filozofia, teologia, historia Kościoła, czasopisma, Kraków 1930; idem, Co czytać? Poradnik dla czytających ksiązki. Beletrystyka, Kraków 1932; F. Machay, Niebezpieczeństwo pornografii, w: Walka z pornografia (Cykl rozpraw), Poznań 1932; Cz. Lechicki, W walce z demoralizacją. Szkice literacko-społeczne, t. 1-2, Miejsce Piastowe 1932-1933; Z. Baranowski, Bezwstyd w literaturze i obrazku, w: Walka z pornografia. (Cykl rozpraw), Poznań 1932, s. 17-20.

${ }_{35}$ B. Hadaczek, Wychowanie przez literature w Polsce międzywojennej (zwiąki literatury dla dzieci i młodzieży z pedagogika), Warszawa - Poznań 1973. 
W 1939 r. w Lwowskiej Bibliotece Publicznej wydał Kuchta swą książkę pt. Nowe kierunki i dążenia katolickiej pedagogiki na tle obrazu chaosu we współczesnym wychowaniu. Autor pragnął przedstawić współczesne mu kierunki niekatolickiej i katolickiej pedagogiki w Europie i poza nią, ukazać, do ,jakiego chaosu doprowadził tu tragiczny zamęt w świecie wartości współczesnego człowieka" ${ }^{36}$. Kuchta wyrażał pogląd, że ideałom wychowawczym brak najwyższego celu wychowawczego, zapomina się o ostatecznym celu wychowania, o ideale najwyższym, przerastajacym człowieka, narody, kraje i części ziemi - o Chrystusie i Jego nauce! $!^{37}$.

Kuchta analizował stan ówczesnego wychowania w Rosji Sowieckiej. Nie szczędził mu ostrej krytyki, uznając, że człowieka w systemie komunistycznym traktuje się jak maszynę, która nie posiada duszy. Irytował go również kierunek w pedagogice propagowany w Anglii przez Bertranda Russela - znanego logika i pedagoga z Cambridge. Określał go jako kierunek pedagogiki indywidualnej, internacjonalnej: B. Russel uważa, - wyjaśniał Kuchta - że sposoby wychowania należy radykalnie zmienić; będzie to jednak naprawdę możliwe dopiero w „nowym ustroju społecznym”, do którego dązy. Przebudowa społeczna oprzeć się musi o „naukowy pogląd na świat”. Cóż w tej chwili przeszkadza tej „,przebudowie”? Otóż: Religia, nacjonalizm, własność i dogmatyzm doktryn klasowo-społecznych ${ }^{38}$. Dla Kuchty wielce wymowne było motto do książki Russela pt. Podbój szczęścia, gdzie zamieszczone zostały słowa Walt’a Whitmana:

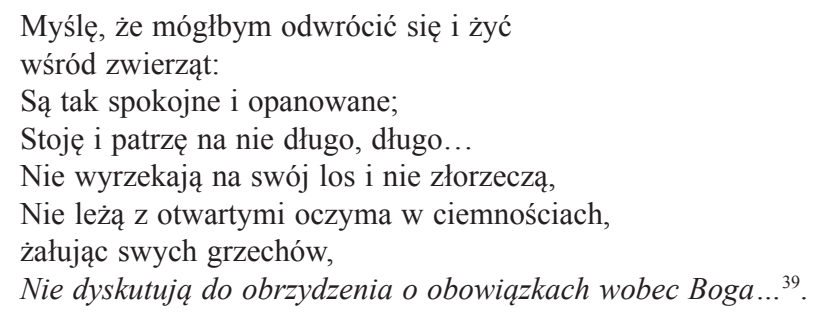

Polski autor wykazywał, że „,pedagogika instynktów” i ,internacjonalna indywidualna pedagogika, z zachowaniem swobody jednostki”, której hołduje Russel, jest wielkim złem, doprowadza do ,potwornych błędów moralnych jedynie”. Za szczególnie niebezpieczne dla wychowania uznawał odrzucenie wartości religijnych.

Dla Kuchty nie do przyjęcia były również idee wychowawcze propagowane przez pioniera narodowo-socjalistycznej pedagogiki Ernesta Kriecka, a wyrażone w dziele pt. Erziehung im Nationalsozialistischen Staat $(1938)^{40}$. Nie godził się też z ideologią wy-

\footnotetext{
${ }^{36}$ J. Kuchta, Nowe kierunki i dążenia współczesnej katolickiej pedagogiki (na tle obrazu chaosu we wspótczesnym wychowaniu), Lwów 1939, s. 10.

37 Ibidem, s. 17.

38 Ibidem, s. 23.

39 Ibidem, s. 24.

${ }^{40}$ Krytykę myśli pedagogicznej propagowanej przez nazistów przeprowadzili także: Z. Mysłakowski, Totalizm czy kultura, Kraków 1938; ks. J. Pastuszka, Filozoficzne i społeczne idee A. Hitlera, Lublin 1938.
} 
chowania szerzoną przez włoskich faszystów, a szczególnie przez Giovanniego Gentilego, ministra oświaty w rządzie Włoch, a także jego współpracownika Giuseppe Lombardo-Radice. Z kolei amerykański system wychowania postrzegał jako „spłycający życie duchowe" jednostki, wprowadzający na miejsce takich cnót, jak honor, tradycja, kult dla praktyczności, przedsiębiorczości.

Kuchta sporo uwagi poświęcił przedstawieniu poglądów wybitnych katolickich pedagogów ${ }^{41}$, podkreślając, że pedagogika katolicka różni się od innych systemów pedagogicznych tym przede wszystkim, ̇̇e formułujac swe ,cele wychowawcze”, ma na oku całego człowieka - jego duszę i jego ciało, doczesne życie $i$ wieczność. Wychowuje nie tylko przez życie do życia, ale i przez życie do Boga, do wiecznościt2. Autor omówił poglądy zasłużonych katolickich pedagogów działających w okresie poprzedzającym I wojnę światową, jak: John Lancaster Spalding, Felix Dupanloup, John Henry Newman, Dezydery J. Mercier, Otto Willmann, św. Jan Bosco, Francesco Olgiati, brat Albert (Adam Chmielowski), ks. Bronisław Markiewicz, Maria Marcelina Darowska. Następnie traktował o katolickiej myśli pedagogicznej okresu dwudziestolecia międzywojennego, uznając, że w tym czasie najbardziej owocna była twórczość Belga, profesora pedagogiki na uniwersytecie w Gandawie i Brukseli - ks. Franciszka De Hovre. Kuchta wspominał także o takich myślicielach i krzewicielach katolickich ideałów pedagogicznych, jak: ks. Bronisław Kulesza, Fryderyk von Hügel, ks. Stanisław Dunin-Borkowski, ks. Romano Guardini, Fryderyk Schneider.

\section{Socjologia}

Po zakończeniu I wojny światowej palącym zagadnieniem społecznym stało się włóczęgostwo dzieci i młodzieży, uwidaczniające się szczególnie w większych miastach. Problem ten wystąpił ze zdwojoną siłą w okresie wielkiego kryzysu gospodarczego z przełomu lat 20. i 30. W parze z nędzą materialną postępowała degeneracja duchowa ubogich warstw społeczeństwa. Tym niepokojącym problemem zajęli się naukowo specjaliści z różnych dziedzin wiedzy, w tym również socjologii.

Badacze zajmowali się dziećmi ulicy, włóczęgami. Za pioniera badań nad fenomenologią dzieci trudnych uchodził w czasach II Rzeczypospolitej Zygmunt Mysłakowski ${ }^{43}$. Uczestnikiem prowadzonego przez niego seminarium socjologicznego na Uniwersytecie Jagiellońskim był J. Kuchta. Swe dzieło Dziecko włóczęga, wydane w 1933 r. ${ }^{44}$, zadedy-

${ }^{41}$ W okresie międzywojennym tą problematyką zajmowali się również: K. Michalski, Katolicka myśl wychowawcza, Poznań 1937; L. Siemieńska, Główne kierunki wspótczesnej pedagogiki. Pedagogika religijna, Lwów 1936; zob. także: S.I. Możdżeń, Inspiracje katolickiej myśli wychowawczej w Polsce do połowy XX wie$k u$, Kielce 2001.

42 J. Kuchta, Nowe kierunki..., s. 49.

43 J. Dybiec, Uniwersytet Jagielloński 1918-1939, Kraków 2000, s. 452.

44 Jego fragmenty ogłaszał Kuchta na łamach „Chowanny”. Zob.: J. Kuchta, Zabawy krakowskich „,dzieciwłóczęgów” w porze zimowej, „Chowanna” t. 1, 1929, s. 195-207; idem, Dążenia do kompensacji u dziecka - włóczęgi a postawa wychowawcza, „Chowanna” t. 2, 1930, s. 69-90. 
kował krakowskiemu profesorowi, z którego pomocy i życzliwości korzystał w trakcie przygotowywania rozprawy. Wykorzystał w niej literaturę polską ${ }^{45}$, angielską, francuską, niemiecką, rosyjską, włoską, ponadto przeprowadził badania terenowe. Przedstawił sylwetki dzieci-włóczęgów, dokonał próby ich podziału na typy z punktu widzenia socjologii (m.in. dziecko włóczęga zdobywające środki do życia wyłącznie przez pracę sezonową; dziecko włóczęga żyjące z żebraniny; dziecko włóczęga żyjące wyłącznie z kradzieży), opisał organizacje dzieci-włóczęgów, dążenia do kompensacji u dziecka-włóczęgi. W końcowych rozdziałach swej pracy poruszył zagadnienie instynktu włóczęgowskiego - jako jednej z przyczyn aspołeczności dziecka-włóczęgi (analiza możliwości ewolucji i przeobrażeń), a także przybliżył problematykę zabawy krakowskich dzieci-włóczęgów w porze zimowej"6.

Książka Kuchty Dziecko włóczęga spotkała się z żywym zainteresowaniem ze strony recenzentów. Jeden z nich widział w tej rozprawie ,szereg ogólniejszych, podstawowych problemów pedagogicznych, jasno a głęboko zanalizowanych"47. Wypowiadano twierdzenie, że jest to studium napisane ,z wielkim umiłowaniem i znajomością przedmiotu, a przy tym żywo i przystępnie"48. Poznański socjolog - Jan Szczepański stwierdził, że główną zasługą Kuchty jest zebranie „wyjątków, cytatów oraz przykładów i utworzenie z nich pewnej całości użytecznej dla praktyka-wychowawcy, lecz o niewielkiej wartości teoretycznej”. „Zajęcie stanowiska - pisał recenzent - wobec pracy dra Kuchty utrudnia jej kompilacyjny charakter. Poza tym autor, pragnąc wyczerpać temat, sięgał do psychologii i socjologii, splatając zagadnienia psychologiczne, socjologiczne i wychowawcze. Ucierpiała na tym teoretyczna strona książki, nie oparta na jednolitej podstawie teoretycznej, przerzucanej od psychologii do socjologii, co nie zawsze pozwala się uzgodnić. Na przykład, omawiając bandę dzieci, autor za Thrasher'em odrzuca instynkt w rozważaniach socjologicznych, a wraca do niego w rozważaniach psychologicznych. Teorie psychologiczne (kompensacja, instynkt) nie mają dla socjologa znaczenia. Socjolog chętnie z nich zrezygnuje, gdyż wnoszą mu tylko zamęt i chaos. „Zagadnienia włóczęgostwa dzieci normalnych mieszczą się całkowicie w socjologii i pozwalają się opracować bez uciekania się do mętnej koncepcji instynktu. Wypadki patologiczne - stany chorobowe

${ }^{45}$ M.in.: J. Kretz-Mirski, Psychologia i patologia włóczęgi w wieku dziecięcym i młodzieńczym, Lwów 1914; S. Hamczyk, Wynik badania inteligencji nieletnich przestępców, Warszawa 1917; E. Lublinerowa, Dziecko-włóczęga, Warszawa 1922; W. Mikłaszewski, Nieletni przestępcy, Warszawa 1924; A. Mogilnicki, Dziecko i przestępstwo, Warszawa 1925; A. Komorowski, Nieletni przestępcy, Warszawa 1929; S. Batawia, J. Budkiewicz, M. Skrzywan-Żebrowska, Badania nad nieletnimi przestępcami. Poczucia moralne, Warszawa 1929; J.C. Babicki, Wychowanie dziecka opuszczonego w zakładach opiekuńczo-wychowawczych. Cz. 1. Założenia teoretyczne, Warszawa 1929; S. Batawia, Wstęp do nauki o przestępcy, Warszawa 1931; S. Borowiecki, Stosunek jednostki do otoczenia w nerwicach, Warszawa 1932; W. Dzierzbicki, Brodiaga, Warszawa 1933; S. Szpotański, Bez miejsca na świecie, Warszawa 1933.

46 J. Kuchta, Dziecko włóczęga, Warszawa 1933.

${ }^{47}$ Recenzja, „Miesięcznik Pedagogiczny” 1933, nr 11, s. 286-287.

${ }^{48}$ S. Skalski, recenzja, „Kultura Pedagogiczna” t. 1, 1933, s. 464. 
- należą do psychiatrii”"49. Szczepański uważał, że monografia Kuchty wskazuje na istotne problemy, ale nie mówi, jak należy dążyć do ich rozwiązania.

Powyższa, a także inne prace ${ }^{50}$ Kuchty poświęcone socjologii dziecka opisywały dosyć szczegółowo warunki życia młodych ludzi z różnych środowisk. Cechowała je jednak - jak zauważa współczesny uczony W. Wincławski - „nikła wartość interpretacyjna”. Kuchta „odwoływał się przede wszystkim do drugorzędnego niemieckiego piśmiennictwa antropo-psychologicznego" ${ }^{51}$.

\section{Prace recenzyjne}

Znaczną część publikacji Kuchty stanowiły recenzje i oceny prac innych autorów. Pisał także wstępy do książek oraz tłumaczył prace psychologiczno-pedagogiczne z języków obcych na polski ${ }^{52}$. W roku 1937 w Lwowskiej Biblioteczce Pedagogicznej ukazała się rozprawa Jadwigi Szmydt pt. Prof. Dr Piotr Bovet twórca podstaw nowoczesnego wychowania moralnego. Wydaniem tej pracy chciano uczcić przypadającą wówczas 60-letnią rocznicę urodzin Boveta - profesora Uniwersytetu w Genewie, dyrektora Instytutu J. J. Rousseau'a. W przedmowie do studium Kuchta przybliżył czytelnikom zasługi genewskiego pedagoga, wykazując, że stworzył on psychologiczne podstawy wychowania moralnego: Potrafit on bowiem, wznióstszy się ponad wszystko to, co ludzi dzieli i różni, ukochać w nich ,ludzkość” i poprowadzić współczesnego człowieka ku najwyższym wyżynom moralnym, na jakie tylko „ludzkość” $i$ „,czlowieczeństwo” wznieść się jednostkom i narodom pozwala, ku fazie trzeciej i najdoskonalszej ,,miłości ludzkości" „53. Kuchta przekazał, że wydane w języku polskim dzieła Boveta pt. Instynkt walki oraz Psychoanaliza a wychowanie są cenione przez polskich odbiorów.

W redagowanej przez J. Kuchtę Licealnej Biblioteczce Filozoficznej ukazała się w 1938 r. praca Józefa Pietera Odwaga. Próba psychologicznej analizy. W przedmowie do tej książeczki redaktor wypowiedział twierdzenie, że studium Pietera stanowi wnikliwa psychologiczna analize strachu, lęku i odwagi!54. Kuchta uważał, że rozprawka Pietera może dać impuls do rozważenia dalszych problemów związanych z odwagą, takich jak: stosunek jednostki do zbiorowości, rola typów „,pozytywnych” i „,negatywnych” w społeczeństwie, etyka żołnierza, wodza, obywatela, charakter żołnierski, psychologiczna analiza walki.

\footnotetext{
49 J. Szczepański, recenzja, „Przegląd Socjologiczny” t. 3, 1935, z. 1-2, s. 342-343; por. H. S., recenzja, „Kwartalnik Pedagogiczny”, 1934, nr 2, s. 179-181.

50 J. Kuchta, Dzieci trudne do wychowania, cz. 1, Lwów 1936; cz. 2, Lwów 1937.

51 W. Wincławski, Kuchta Jan Andrzej (1900- ?), w: Słownik biograficzny socjologii polskiej, s. 177.

${ }^{52}$ E. Croner, Dzisiejsze młode dziewczę, tłum. J. Kuchta, Warszawa 1931; eadem, Psychika młodzieży żeńskiej, Lwów 1932 [wraz z J. Lubomorowicz].

53 J. Kuchta, Przedmowa, w: J. Szmydt, Prof. Dr Piotr Bonet twórca podstaw nowoczesnego wychowania moralnego, Lwów 1937, s. 3.

54 J. Kuchta, Przemowa, w: J. Pieter, Odwaga. Próba psychologicznej analizy, Lwów 1938, s. 4.
} 
Dużą uwagę, już od początku swej pracy naukowej ${ }^{55}$, przykładał Kuchta do recenzji nowości wydawniczych. W 1929 r., w Bibliotece Dzieł Pedagogicznych, ukazało się studium Geraldine Coster pt. Psychoanaliza w zastosowaniu do ludzi normalnych ${ }^{56}$. Kuchta w recenzji podkreślił wielką zaletę tej pracy, która jego zdaniem polega na tym, że Coster poprzedziła swe rozważania wyjaśnieniem terminów związanych z psychoanalizą. Następnie omówił strukturę recenzowanej pracy, zaznaczając, że jej główna część poświęcona jest dwu instynktom, dominującym w życiu człowieka, tj. instynktowi władzy i instynktowi płciowemu. Za oryginalne uznał Kuchta poglądy Coster na „sublimację”: Szereg - pisał - trafnych i subtelnych a zarazem z wielka siła przekonywujaca wypowiedzianych uwag na ten temat, którego omawiania z powodu trudności tematu, nie każdy autor podjąby się, stanowi o doniostej wartości pracy G. Coster dla wychowawcy ${ }^{57}$. Recenzent był przekonany, że praca Coster, w znakomitym polskim tłumaczeniu, wywrze doniosły wpływ na rozpowszechnione dość nieścisłe wiadomości z dziedziny psychologii analitycznej ${ }^{58}$.

Kuchta oceniał także twórczość jednego ze swych mistrzów - Stefana Szumana. Napisał recenzję jego pracy Wpływ bajki na psychikę dziecka ${ }^{59}$, stwierdzając, że stanowi ona znakomite ujęcie problematyki, pionierskie na gruncie polskim, popularyzujące osiągnięcia nowoczesnej nauki. Zbadat bowiem - pisał recenzent - i utrwalit objawy wptywu bajki na wrażliwość uczuciową czteroletniego dziecka (a więc będącego właśnie w ,wieku bajki”), robiąc zdjęcia kinematograficzne jego mimiki, podczas opowiadania różnych bajek. Zbadat nadto ich wptyw na późniejsze zachowanie się dziecka, studiując dtuższy czas ich nastęstwa ${ }^{60}$. Kuchta dokonał również oceny rozprawy Szumana pt. Badania nad rozwojem rozumienia obrazów o symbolicznej treści u dzieci i młodzieży ${ }^{61}$. Osiągnięcia naukowe Szumana były powszechnie cenione przez specjalistów okresu międzywojnia.

Przedmiotem analiz Kuchty stała się rozprawa Zasady nauczania Bogdana Nawroczyńskiego ${ }^{62}$. Nazywał ją prawdziwym klejnotem wśród literatury pedagogicznej, zaliczając do najbardziej cennych jej rozdziałów traktujące o zasadzie poglądowości w nauczaniu oraz o formach nauczania. Kuchta dawał wyraz przekonaniu, że książka Nawroczyńskiego będzie niewatpliwie ta podstawowa praca, na której dtugie lata ksztatcić się będa nie tylko szeregi młodzieży uniwersyteckiej, poświęcającej się zawodowi nauczycielskiemu, ale z której czerpać będa rzetelna i gruntowna ,, wiedzę dydaktyczna, nowa" wszyscy juz dziś i od lat czynni nauczyciele szkół wszystkich kategorii - przetwa-

\footnotetext{
s. $146-149$.

${ }^{56}$ G. Coster, Psychoanaliza w zastosowaniu do ludzi normalnych, tł. M. Górska, Warszawa 1929.

57 J. Kuchta, recenzja, „Ruch Pedagogiczny” 1930, nr 2, s. 92.

58 Ibidem.

59 S. Szuman, Wplyw bajki na psychikę dziecka, Warszawa 1928.

${ }^{60}$ J. Kuchta, recenzja, „Ruch Pedagogiczny” 1930, nr 2, s. 92-93.

${ }^{6} \mathrm{~S}$. Szuman, Badania nad rozwojem rozumienia obrazów o symbolicznej treści u dzieci i młodzieży, Kraków 1931; J. Kuchta, recenzja, „Muzeum” 1931, s. 313-316.

${ }^{62}$ B. Nawroczyński, Zasady nauczania, Lwów - Warszawa 1930.
} 
rzając pod jej wpływem dawnego „,ducha szkoły” w kierunku przez autora wskazanym ${ }^{63}$. Kuchta dostrzegał wady współczesnej mu dydaktyki, głęboko wierzył, że rozwój nauk pedagogicznych i fachowej literatury przyczyni się do ich usunięcia, usprawnienia procesu nauczania.

Na łamach „Ruchu Pedagogicznego” zrecenzował Kuchta rozprawę Władysława Sterlinga pt. Dziecko moralnie upośledzone ${ }^{64}$, uznając, iż wypełnia ona dotkliwą lukę w polskim piśmiennictwie pedagogicznym. Sterling poruszył dwojakie zagadnienie: dokonał charakterystyki psychologicznej dzieci moralnie upośledzonych, a także zwrócił uwagę na pewne nowe poczynania wychowawcze w odniesieniu do nich i ich kształcenia moralnego. Kuchta oceniał jako trafne uwagi Sterlinga o psychologicznym mechanizmie moralnego upośledzenia wrodzonego i nabytego. W zakończeniu recenzji stwierdził, że jego monografia podaje bardzo wiele materiatu faktycznego, chociaż $w$ formie bardzo skondensowanej, autor bowiem dażyt do tego, by wszystkie istotne problemy z zagadnieniem związane omówić. Toteż czytelnik z jej przeczytania odniesie prawdziwa i głęboka korzyść; z jednej strony jest to bowiem pierwsza polska syntetyczna praca z tej dziedziny, $z$ drugiej autor $z$ wielka, właściwa sobie sumiennościa $i$ gruntownościa opracowat zagadnienie, którego omówienia się podją ${ }^{65}$. Kuchta wspominał w recenzji także o innej pracy Sterlinga, a noszącej tytuł Dziecko umysłowo upośledzone. Wysoko oceniał jej wartość merytoryczną.

Kuchta przybliżył także w swych recenzjach treść książek pióra takich znanych autorów, jak np. John Alford Stevenson ${ }^{66}$, Alfred Adler ${ }^{67}$, Józef Czesław Babicki ${ }^{68}$ oraz Stefan Baley ${ }^{69}$. Wiedzę w nich przekazaną oceniał jako nowatorską, ukazującą nowe tendencje w ówczesnej pedagogice i psychologii. Większość recenzji Kuchty miała charakter sprawozdawczy.

Działalność naukowa Jana Kuchty uwidoczniła się przede wszystkim w jego twórczości pisarskiej, dosyć bogatej pod względem ilościowym i zróżnicowanej treściowo. Oprócz rozpraw książkowych, ogłosił wiele artykułów i recenzji, współpracując z takimi czasopismami, jak: „Chowana”, „Lud”, „Miesięcznik Pedagogiczny”, „Muzeum”, „Ruch Pedagogiczny". Niektóre artykuły weszły w skład wydawanych w późniejszym okresie książek. Kuchta nie był wybijającą się postacią w środowisku naukowym II Rzeczypospolitej. Przeważająca część recenzentów jego prac zarzucała im powierzchowność, słabe ujęcie poruszanej problematyki. Zasługą Kuchty było przeszczepianie na grunt polski najnowszych osiągnięć zagranicznej psychologii, pedagogii oraz socjologii. Czynił to

63 J. Kuchta, recenzja, „Muzeum” 1931, s. 40-42.

${ }^{64}$ W. Sterling, Dziecko moralnie upośledzone, Warszawa 1929.

${ }^{65}$ J. Kuchta, recenzja, „Ruch Pedagogiczny” 1931, nr 2, s. 86-88.

${ }^{66}$ J.A. Stevenson, Metoda projektów w nauczaniu, tłum. W. Piniówna, Lwów - Warszawa 1930; J. Kuchta, recenzja, „Muzeum” 1931, s. 42-44.

${ }^{67}$ A. Adler, Schwer erziehbare Kinder, Dresden 1927; J. Kuchta, recenzja, „Chowanna” t. 2, 1930, s. $93-95$.

68 J.C. Babicki, Wychowanie dziecka opuszczonego w zakładach opiekuńczo-wychowawczych, cz. 1. Założenia teoretyczne, Warszawa 1929; J. Kuchta, recenzja, „Chowanna” t. 2, 1930, s. 95-97.

${ }^{69}$ S. Baley, Psychologia mężczyzny i kobiety, Warszawa 1930; J. Kuchta, recenzja, „Muzeum” 1931, s. 164-166. 
głównie przez dokonywanie streszczeń obcojęzycznych prac. Publikacje omawianego autora miały wartość dokumentacyjną, ukazują problemy oświatowo-wychowawcze, a także psychologiczno-socjologiczne czasów II Rzeczypospolitej. Dla współczesnych badaczy interesujących się historią nauki mogą stanowić ważkie źródło informacji o rozwoju wiedzy w okresie międzywojnia. 
